\title{
Evaluation of a rainbow trout (Oncorhynchus mikyss) culture water recirculating system
}

\section{Evaluación de un sistema de recirculación de agua para levante de trucha arcoiris (Oncorhynchus mikyss)}

\author{
Iván Sánchez O,* M.Sc, Wilmer Sanguino O, IPA, Ariel Gómez C, Esp, \\ Roberto García C, IPA.
}

Universidad de Nariño, Faculty of Livestock Sciences, Department of Hydrobiological Resources, Aquaculture Production Engineering Program. Ciudad Universitaria, Barrio Torobajo Carrera 22\#18-109. San Juan de Pasto, Nariño, Colombia. *Correspondence: iaso@udenar.edu.co.

Received: July 2013; Accepted: February 2014.

\begin{abstract}
Objective. To evaluate a water recirculation system for rainbow trout fish cultures at the recirculating laboratory of the Aquaculture Engineering Production Program of University of Nariño. Materials and Methods. 324 rainbow trout (Oncorhynchus mikyss) fries were cultured in 12 plastic tanks with a capacity of $250 \mathrm{~L}$ in an aquaculture recirculating system the treatment system of which was made up by a conventional sedimentation tank, a fixed stand upflow biofilter with recycled PVC tube pieces and a natural degassing system; the sedimentation unit effluent was pumped up to a reservoir tank using a 2 HP centrifugal pump after being subject to gravity through the biofilter and to be then distributed to the 12 culture units to which a constant amount of air from a blower was injected. Results. The water treatment system removed $31 \%$ of total suspended solids, $9.5 \%$ of total ammonia nitrogen, and increased dissolved oxygen to the final effluent in $6.5 \%$. An increase of $305 \%$ in biomass was calculated during 75 days, the mortality percentage registered throughout the study period was $4.9 \%$. Conclusions. The water treatment system maintained the physicochemical water quality parameters within the values recommended for the species. The increase in weight and size, food conversion, mortality and biomass production reported normal values for rainbow trout fish culture in recirculating systems.
\end{abstract}

Key words: Aquaculture, cultivation, treatment, trout, water recirculation (Source: $C A B, D e C S$ ).

\section{RESUMEN}

Objetivo. Evaluar un sistema de recirculación de agua para cultivo de trucha arcoiris en el laboratorio de recirculación del Programa Ingeniería en Producción Acuícola de la Universidad de Nariño. Materiales y métodos. Se cultivaron 324 alevinos de trucha arco íris (Oncorhynchus mikyss) en 12 tanques plásticos de $250 \mathrm{~L}$ de capacidad en un sistema de recirculación para acuacultura cuyo sistema de tratamiento estuvo constituido por un sedimentador convencional, un biofiltro de flujo ascendente con medio soporte fijo conformado por segmentos reciclados de tubos PVC, y un sistema de desgasificación natural; el efluente del sedimentador fue elevado a un tanque reservorio por medio de una bomba centrífuga de 2 HP para después pasar por gravedad a través del biofiltro y posteriormente ser distribuido a las 12 unidades de cultivo a las que de manera permanente se inyectó aire proveniente de un blówer. 
Resultados. El sistema de tratamiento del agua removió $31 \%$ de los sólidos suspendidos totales; $9.5 \%$ del nitrógeno amoniacal total, e incrementó el oxígeno disuelto al efluente final en un $6.5 \%$. Se calculó un incremento de la biomasa del $345 \%$ en los 75 días, el porcentaje de mortalidad registrado durante todo el periodo de estudio fue del $4.9 \%$. Conclusiones. El sistema de tratamiento mantuvo los parámetros físico-químicos de la calidad de agua dentro de los rangos requeridos por la especie. El incremento de peso y talla, la conversión alimenticia, la mortalidad y la producción de biomasa reportaron valores normales para producción de trucha en sistemas de recirculación.

Palabras clave: Acuicultura, cultivo, recirculación del agua, tratamiento, trucha (Fuente: $C A B, D e C S$ ).

\section{INTRODUCTION}

The high deterioration of productive soils caused by overexploitation processes makes possible discerning that aquaculture will be the future, since development and population growth levels increase every day, requiring nutritive and high quality food; however, the availability and quality of water has been impacted by both natural and anthropogenic activities, leading to the low quality of the liquid and reduced productivity in aquatic ecosystems, therefore water pollution has become a serious problem for the industry (1).

The aspects that limit the growth of aquaculture include the reduction of cultivable water bodies, as well as increased pollution of surface water with harmful chemicals and the eutrophication of rivers and lakes with excesses of nutrients which can lead to various problems such as toxic algal blooms, low concentrations of dissolved oxygen, dead fish and biodiversity reduction (2).

Contaminants may exert their action on aquaculture cultures in any of the following ways: by modifying the hydrobiological characteristics of water; through the direct action of bio-acid substances that may cause physiological changes or high mortality; or by the contamination of animal tissues with biotoxins, pathogens or chemicals that render animals unusable for consumption (3).

Water is a natural resource whose location and geographic distribution is dramatically affected by anthropogenic actions, an example of this is the alteration in the availability of the liquid due to the climate change induced by human beings (4), which is expressed as the longterm variations in average weather conditions at multiple temporal and spatial scales, and may represent a natural threat, such as floods, droughts, cold or heat waves and storms (5).

Water scarcity and the increasing negative alteration of its characteristics make it

\section{INTRODUCCIÓN}

El elevado deterioro de los suelos productivos por procesos de sobreexplotación hace vislumbrar que la acuacultura será el futuro, puesto que los niveles de desarrollo y crecimiento de la población aumentan día a día, precisando de alimentos nutritivos y de alta calidad; sin embargo, la disponibilidad y calidad del agua ha sido impactada por actividades tanto naturales como antropogénicas, conduciendo a la baja calidad del líquido y una reducida productividad en ecosistemas acuáticos, por ello la contaminación del agua se ha convertido en un grave problema para la industria acuícola (1).

Entre los aspectos que limitan el crecimiento de la acuacultura está la reducción de los cuerpos de agua cultivables, así como la creciente contaminación de las aguas superficiales con químicos perjudiciales y la eutroficación de ríos y lagos con excesos de nutrientes que pueden conducir a diversos problemas como las floraciones de algas tóxicas, bajas concentraciones de oxígeno disuelto, muerte de peces y reducción en la biodiversidad (2).

Los contaminantes pueden ejercer su acción sobre los cultivos acuícolas de alguna de las siguientes formas: modificando las características hidrobiológicas del agua; mediante una acción directa de substancias biocidas que pueden originar alteraciones fisiológicas o grandes mortalidades; o por contaminación de los tejidos animales con biotoxinas, microorganismos patógenos o productos químicos que inutilizan a los animales para el consumo (3).

El agua es un recurso natural cuya localización y distribución geográfica es dramáticamente afectada por las acciones antrópicas, un ejemplo de ello es la alteración en la disponibilidad del líquido debido al cambio climático inducido por el ser humano (4), el cual se expresa como la modificación a largo plazo de las condiciones meteorológicas medias con variaciones en múltiples escalas temporales y espaciales, y pueden representar una amenaza natural, como inundaciones, sequías, olas de frío o de calor y tormentas (5). 
necessary to investigate the use of intensive and semi-intensive production techniques for hydrobiological species, such as aquaculture recirculating systems (ARS). ARSs were developed as a technology for intensive fish production and have been mainly used when water availability is limited because they allow recycling between 90 and $99 \%$ of the liquid (6). Generally, an ARS consists of mechanical and biological filtration components, cultivation tanks, pumps, and may include additional elements for water treatment and disease control in the system (7).

ARSs are a technology that allows fish culturing at a greater intensity under a completely controlled environment where animals are bred in tanks under the safest possible conditions. In addition, in such systems the reuse of water after its physical and biological treatment is accomplished as a response to the attempt to reduce water and energy needs as well as the emission of nutrients to the environment (8).

Due to the importance of the maintenance of water quality in recirculating systems, virtually all wastewater treatment levels described by von Sperling (9) are applied, because they range from preliminary treatment devices that remove elements that may cause operation and maintenance problems, systems for the removal of suspended solids, to the removal of organic solids, nutrients and disinfection by means of physical, chemical and/or biological processes. In the ARSs, the main application of biological treatment processes is the removal of biodegradable organic substances present in wastewater in both colloidal and dissolved form. The biological treatment is based on a process in which a mixed population of microorganisms uses water pollutants as nutrients, which when in contact for sufficient time allows these microorganisms to break down and eliminate polluting solutes as appropriate.

In year 2010, diadromous fish accounted for $6 \%$ of world aquaculture production, of which the trout ranked third with about 0.7 million tons (10). Trout farming requires waters of an excellent quality, in which suspended solids do not exceed $10 \mathrm{mg} / \mathrm{l}$, total ammoniacal nitrogen of less than $1 \mathrm{mg} / \mathrm{l}$, ammonia below $0.02 \mathrm{mg} / \mathrm{l}$, nitrite below $0.1 \mathrm{mg} / \mathrm{l}$, temperatures between 10 and $18^{\circ} \mathrm{C}$ and dissolved oxygen concentrations between 6 and $8 \mathrm{mg} / \mathrm{l}$ (11).

The main objective of this research was to monitor a water recirculating system for rainbow trout cultivation (Oncorhynchus mikyss) in its culturing phase in terms of the efficiency in
La escasez del agua y la creciente alteración negativa de sus características hacen necesario investigar en relación al uso de técnicas de producción semiintensiva e intensiva de especies hidrobiológicas, como los sistemas de recirculación para acuicultura (SRA). Los SRA se desarrollaron como una tecnología para la producción intensiva de peces y han sido principalmente utilizados cuando la disponibilidad del agua es limitada pues permiten el reciclaje de entre el 90 y el 99\% del líquido (6). Generalmente, un SRA está constituido por componentes de filtración mecánica y biológica, bombas, tanques de cultivo, y puede incluir elementos adicionales para tratamiento del agua y control de enfermedades en el sistema (7).

Los SRA son la tecnología que permite el cultivo de peces a mayor intensidad bajo un ambiente totalmente controlado en donde los animales se crían en tanques en las condiciones más seguras posibles. Adicionalmente, en tales sistemas el reuso del agua después de su tratamiento físico y biológico se logra como respuesta al intento de reducir las necesidades de agua y energía, así como la emisión de nutrientes al ambiente (8).

Debido a la importancia del mantenimiento de la calidad del agua en sistemas de recirculación, prácticamente se implementan todos los niveles de tratamiento de aguas residuales descritos por von Sperling (9), pues se involucran desde dispositivos para tratamiento preliminar que remueven elementos que puedan provocar problemas de operación y mantenimiento, pasando por sistemas para remoción de sólidos suspendidos, hasta la remoción de materia orgánica, nutrientes y desinfección por medio de procesos físicos, químicos y/o biológicos. En los SRA's La principal aplicación de los procesos de tratamiento biológico es la eliminación de las sustancias orgánicas biodegradables presentes en el agua residual en forma tanto coloidal, como en disolución. El tratamiento biológico se basa en un proceso en el que una población mixta de microorganismos utiliza como nutrientes sustancias que contaminan el agua, que al estar en contacto durante un tiempo suficiente le permite a dichos microorganismos descomponer y eliminar según se desee los solutos contaminantes.

En el año 2010, los peces diádromos representaron el $6 \%$ de la producción acuícola mundial, de los cuales la trucha ocupó el tercer lugar con cerca de 0.7 millones de toneladas (10). El cultivo de trucha requiere de aguas de excelente calidad, en la cual los sólidos suspendidos no superen $10 \mathrm{mg} / \mathrm{l}$, nitrógeno amoniacal total menor de $1 \mathrm{mg} / \mathrm{l}$, amoníaco menor de $0.02 \mathrm{mg} / \mathrm{l}$, nitrito por debajo de $0.1 \mathrm{mg} / \mathrm{l}$, temperaturas entre 10 y $18^{\circ} \mathrm{C}$ y concentraciones de oxígeno disuelto entre 6 y 8 mg/l (11).

El principal objetivo de la presente investigación fue monitorear un sistema de recirculación de agua 
the removal of solids and ammonium, the contribution to DO concentration and the most important productive variables.

\section{MATERIALS AND METHODS}

Location. The research project was conducted in the Living Organisms Laboratory of the Aquaculture Production Engineering program of University of Nariño, located to the northeast of the city of Pasto, Department of Nariño, $01^{\circ}$ $09^{\prime}$ north latitude, $77^{\circ} 08^{\prime}$ east longitude and an approximate altitude of $2540 \mathrm{~m}$; the multiyear monthly average temperatures of the city vary between 9.3 and $18.1^{\circ} \mathrm{C}(12)$.

Description of the ARS and its operation. The recirculating system evaluated consisted of 12 circular polyethylene tanks with a maximum individual capacity of 250 liters; two 2 HP centrifugal pumps; a conventional sedimentation rectangular tank; an upflow biofilter made of by a tank with a maximum capacity of $1.0 \mathrm{~m}^{3}$, inside which recycled PVC vertical segments with a diameter of $1 / 2$ " and a waterfall degasser tank were included.

Nine cubic meters of drinking water were taken for the operation of the system from the municipal aqueduct and stored in the underground settler, culture units, elevated tank reservoir and auxiliary tanks for the natural removal of residual chlorine. The water circulation cycle began with the opening of the valves of the elevated tanks (reservoir and its passage to the biofilter). Tanks of $1.0 \mathrm{~m}^{3}$ were arranged for the periodic partial replacement of the liquid in the system in which dechlorinated water was stored.

Water and culture storage units were cleaned, disinfected, and filled and emptied three times before being placed into operation.

The effluent of the 12 culture tanks, collected by a sanitary pipe with a diameter of 3 ", passed to a sedimentation tank whose input and output devices were formed by thick-walled weirs. The dimensions of the settler made our from common and waterproof masonry with ceramic veneer and mortar were: total length of $2.3 \mathrm{~m}$ and effective sedimentation length of $1.45 \mathrm{~m} ; 0.50 \mathrm{~m}$ wide and $0.90 \mathrm{~m}$ deep. This device with a surface area of $0.725 \mathrm{~m}^{2}$ and a sedimentation volume of $0.653 \mathrm{~m}^{3}$ was cleaned weekly for the removal of precipitated sludge.

The water, once subjected to pretreatment in the settler, passed to the output chamber which para el cultivo de trucha arco iris (Oncorhynchus mikyss) en su fase de levante en términos de la eficiencia de la remoción de sólidos y amonio, del aporte en la concentración del OD y de las variables productivas más importantes.

\section{MATERIALES Y MÉTODOS}

Localización. El proyecto de investigación se llevó a cabo en el Laboratorio de Organismos Vivos del programa Ingeniería en Producción Acuícola de la Universidad de Nariño, ubicada al noreste de la ciudad de Pasto, departamento de Nariño, con Latitud $01^{\circ} 09^{\prime}$ norte, longitud $77^{\circ} 08^{\prime}$ Oeste y altitud aproximada de $2540 \mathrm{msnm}$; las temperaturas medias mensuales multianuales de la ciudad oscilan entre 9.3 y $18.1^{\circ} \mathrm{C}(12)$.

Descripción del SRA y su funcionamiento. EI sistema de recirculación evaluado constó de 12 tanques circulares de polietileno con una capacidad máxima individual de 250 litros; dos bombas centrífugas de $2 \mathrm{HP}$ de potencia; un sedimentador convencional de sección rectangular; un biofiltro de flujo ascendente constituido por un tanque de $1.0 \mathrm{~m}^{3}$ de capacidad máxima, en cuyo interior se incluyeron segmentos verticales de tubería reciclada de PVC de $1 / 2$ " de diámetro y un tanque desgasificador por medio de caída del agua por gravedad.

Para el funcionamiento del sistema se captaron $9 \mathrm{~m}^{3}$ de agua potable del acueducto municipal y se almacenaron en el sedimentador enterrado, las unidades de cultivo, el tanque reservorio elevado y en tanques auxiliares para la remoción natural del cloro residual. Con la apertura de válvulas de los tanques elevados (reservorio y su paso al biofiltro) se inició el ciclo de circulación del agua. Para sustitución y reposición parcial periódica del líquido en el sistema se dispuso de tanques de $1.0 \mathrm{~m}^{3}$ donde se almacenó agua declorinada.

Las unidades de almacenamiento de agua y de cultivo fueron limpiadas, desinfectadas y sometidas a llenado y vaciado en tres oportunidades antes de ponerlas en funcionamiento.

El efluente de los 12 tanques de cultivo, colectado por medio de tubería sanitaria de 3" de diámetro pasó a un tanque sedimentador cuyos dispositivos de entrada y salida estuvieron conformados por vertederos de pared gruesa. Las dimensiones del sedimentador en mampostería común e impermeabilizado con enchape cerámico y mortero fueron de: $2.3 \mathrm{~m}$ de largo total y $1.45 \mathrm{~m}$ de longitud efectiva de sedimentación; $0.50 \mathrm{~m}$ de ancho y $0.90 \mathrm{~m}$ de profundidad. Este dispositivo con área superficial de $0.725 \mathrm{~m}^{2}$ y volumen de sedimentación 
in turn served as the suction chamber of a 2 HP electric plant that subsequently discharged the liquid onto an elevated tank located at a height of $8 \mathrm{~m}$ in relation to the initial level of culture tanks; said tank was used as temporary storage from where the liquid was discharged towards the biological treatment unit consisting of the upflow biofilter with a maximum capacity of $1 \mathrm{~m}^{3}$, usable volume of $0.750 \mathrm{~m}^{3}$ and a water surface diameter of $0.85 \mathrm{~m}$ (Figure 1A). To ensure the homogenous distribution of the upflow an acrylic plate with holes of $0.5 \mathrm{~cm}$ in diameter was arranged, located at the base of the biofilter and which in turn provided support for the vertical tubes that served as supporting base. The biological community colonizing the surface of the tube segments used as support contributes to the transformation of the ammonium produced in the trout culture into nitrites and nitrates.

The effluent of the biofilter passed to a waterfall aeration system that at the same time served as a degassing mechanism for the removal of gases such as $\mathrm{CO}_{2}$. The water was finally transported to the 12 culture units where the input of the liquid was carried out through a perforated standpipe (Figure 1B), which generated a tangential flow and an adequate turbulence level for the needs of the species. Air from a 2 HP blower was injected through diffuser stones to improve DO conditions in tanks.

The general layout of culture and wastewater treatment units is shown in the diagram of figure 2 .

Study period. The experiment was divided into two phases:

Pretest: It was carried out between July 1 and September 13, 2008, where operating adjustments were made to culturing and water treatment units, as well as to the protocols for de $0.653 \mathrm{~m}^{3}$ se limpió semanalmente para efectos de remoción de los lodos precipitados.

El agua una vez sometida a pretratamiento en el sedimentador pasó a la cámara de salida que a su vez sirvió como cámara de succión de una electrobomba de $2 \mathrm{HP}$ que posteriormente descargó el líquido a un tanque elevado localizado a $8 \mathrm{~m}$ de altura con relación al nivel inicial de los tanques de cultivo; dicho tanque funcionó como medio de almacenamiento temporal desde donde se descargó el líquido hacia la unidad de tratamiento biológico constituida por el biofiltro de flujo ascendente con capacidad máxima de $1 \mathrm{~m}^{3}$, volumen aprovechado de $0.750 \mathrm{~m}^{3}$ y diámetro superficial de la lámina de agua de $0.85 \mathrm{~m}$ (Figura 1A). Para garantizar la distribución homogénea del flujo ascendente se dispuso de una placa acrílica con orificios de 0.5 $\mathrm{cm}$ de diámetro, localizada en la base de biofiltro y que a su vez sirvió de apoyo para los tubos verticales que conformaron el medio de soporte. La comunidad biológica que coloniza la superficie de los segmentos de tubos usados como medio de soporte propicia la transformación del amonio producido en el cultivo de las truchas en nitritos y nitratos.

El efluente del biofiltro pasó hacia un sistema de aireación por caída hidráulica que a la vez sirvió como mecanismo de desgasificación para remoción de gases como el $\mathrm{CO}_{2}$. Finalmente el agua se transportó hacia las 12 unidades de cultivo donde la entrada del líquido se realizó por medio de tubería vertical perforada (Figura 1B) que generó un flujo tangencial y un nivel de turbulencia adecuada a las necesidades de la especie. Para mejorar las condiciones de OD en los tanques se inyectó aire proveniente de un soplador de $2 \mathrm{HP}$ por medio de piedras difusoras.

La disposición general de las unidades de cultivo y de tratamiento del agua residual se presenta en el esquema de la figura 2.

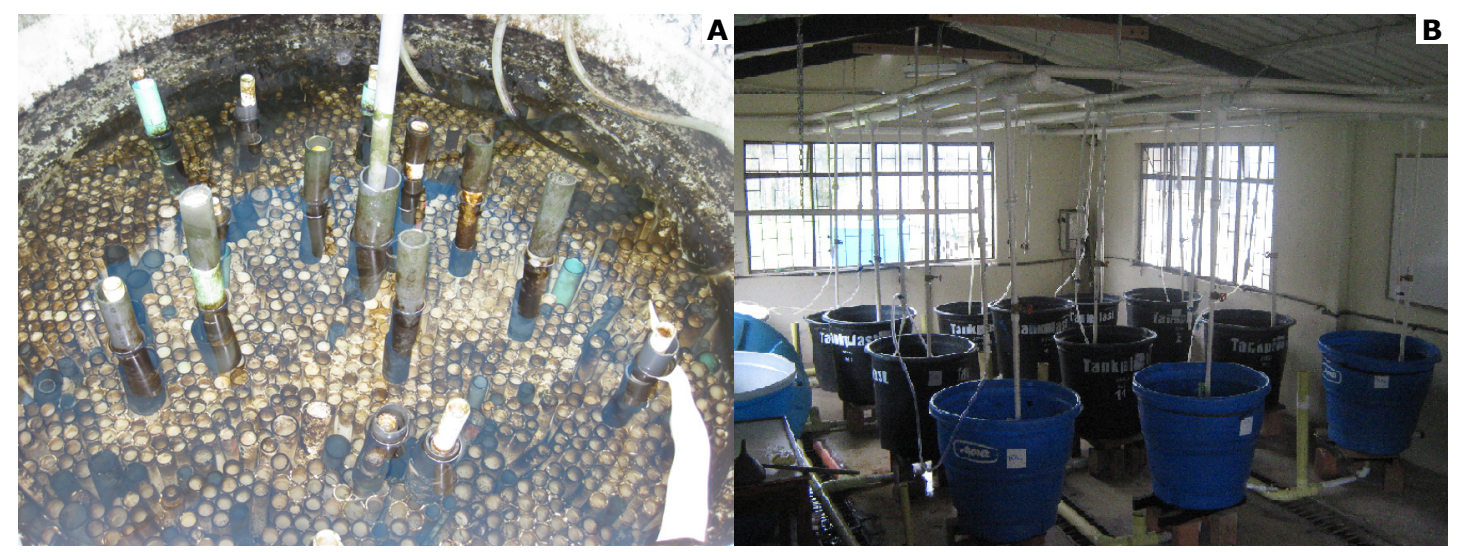

Figure 1. Top view of the biofilter (A); water and air distribution network to culture tanks (B) 


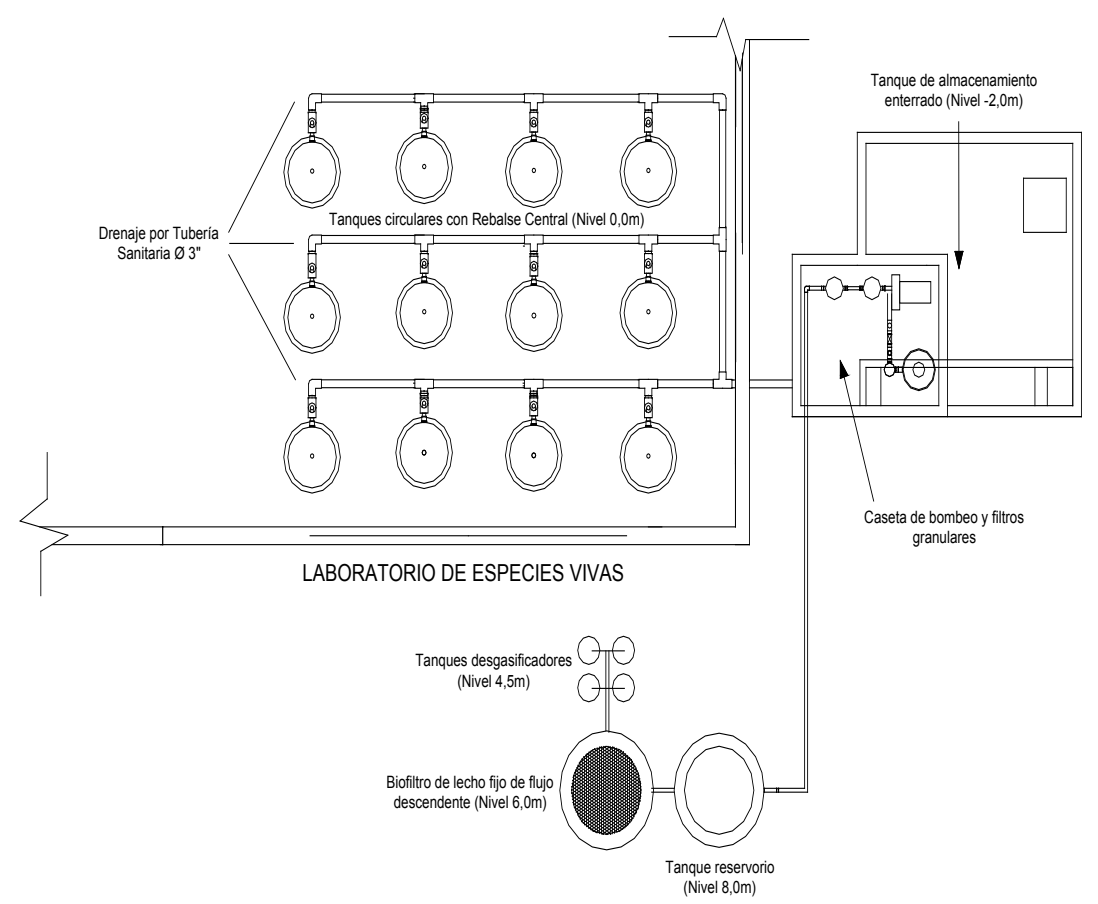

Figure 2. Plan view of the components of the ARS evaluated.

the handling, evaluation and acclimatization of animals.

Test: Performed between September 13 and November 22, 2008, where the operation of the ARS and the variables of productive interest for the cultivation of rainbow trout during the culturing phase were evaluated.

Biological material. In each culture tank 27 rainbow trout fries were cultivated, with an average weight of $32.4 \mathrm{~g}$ and a length of 14.2 $\mathrm{cm}$ for a total of 324 and came from floating cages of the Intiyaco station of the University of Nariño, located in lake Guamues.

Adaptation of experimental units. To maintain a constant water level in culture tanks to the central drainage system, an external lateral overflow pipe was adapted using concentric pipes (Figure 3A) where the effluent from each tank underwent an upward vertical motion in the inner tube, once water reached its upper edge the edge it operated as a horizontal circular weir that caused the fluid evacuated to flow evenly through the space between the two concentric tubes to finally move towards the main pipe for the collection and transport of effluents. Culturing units were cleaned and disinfected with water and commercial chlorine. They were subsequently washed with drinking water and each tank was filled with a net water volume of 235 liters; then ventilation was provided by means of
Periodo de estudio. El experimento tuvo dos fases:

Pre-ensayo: Se llevó a cabo entre el 1 de julio y el 13 de septiembre de 2008 , donde se realizaron los ajustes de funcionamiento de las unidades de cultivo y tratamiento de agua, así como los protocolos de manejo, evaluación y aclimatación de los animales.

Ensayo: Realizado entre el 13 septiembre hasta 22 de noviembre de 2008 , donde se evaluó el funcionamiento del SRA y las variables de interés productivo del cultivo de trucha arcoiris en la fase de levante.

Material biológico. En cada tanque de cultivo se sembraron 27 alevinos de trucha arcoiris, con un peso promedio de $32.4 \mathrm{~g}$ y una longitud de $14.2 \mathrm{~cm}$ para un total de 324 y fueron provenientes de jaulas flotantes de la estación Intiyaco de la Universidad de Nariño, localizada en el lago Guamués.

Adecuación de las unidades experimentales. Para mantener constante el nivel del agua en los tanques de cultivo al drenaje central se le adaptó un rebalse lateral externo por medio de tubos concéntricos (Figura 3A) donde el líquido efluente de cada tanque experimentó un movimiento vertical ascendente por el tubo interno, una vez el agua alcanzaba su borde superior dicho borde funcionó como un vertedero circular horizontal que propició que el líquido evacuado fluyera de manera homogénea a través del espacio comprendido entre los dos tubos concéntricos para finalmente 
medium pore diffuser stones. Once the ARS was put into operation, the inflow of water from each tank was regulated with a flow rate of $50 \mathrm{ml} / \mathrm{s}$, favoring a replacement (R) of 0.85 $\mathrm{R} /$ hour or $20 \mathrm{R} /$ day during the experiment. Culture units were covered with a mesh to avoid animals jumping out from the tanks (Figure 3B).

Transfer of animals. The fish were moved from the Intiyaco station to the laboratory located at University of Nariño, to this end the animals were subject to a fast for a period of 24 hours, they were then packed in groups of 15 specimens in plastic bags with 10 liters of water and oxygen for their transport and subsequent acclimatization.

Acclimatization and farming. The bags with the animals were placed into the culture units for 15 minutes, then they were opened and the water in the bag mixed with the water of the ARS in order to gradually stabilize $\mathrm{pH}$, DO, temperature and alkalinity values. As a prophylactic treatment $15 \mathrm{~g}$ of sea salt was added to each bag for a period of 15 minutes. The acclimated animals were released in each experimental unit for an adaptation period of 15 days, during which time they were fed with food prepared with florfenicol.

Sampling of animals. Samples were taken every 15 days, 12 animals were used which accounted for $44 \%$ of the total population of each experimental unit. To facilitate the handling of fish in order to record weight and size, the specimens were tranquilized with a solution of commercial quinaldine at a concentration of $5.0 \mathrm{mg} / \mathrm{l}$, the activity was carried out in a plastic container with a capacity of 12 liters and the exposure time was from 2 to 3 minutes. Finally, the individuals sampled received a prophylactic wash with potassium permanganate at a concentration of $10 \mathrm{ppm}$. dirigirse hacia la tubería principal de colecta y transporte de efluentes. Las unidades de cultivo se limpiaron, desinfectaron con agua y cloro comercial. Posteriormente se lavaron con agua potable y se llenó cada tanque con un volumen de agua neto de 235 litros; luego se proporcionó aireación por medio de piedras difusoras de poro mediano. Una vez puesto en funcionamiento el SRA se reguló el flujo de entrada de agua de cada tanque con un caudal de $50 \mathrm{ml} / \mathrm{s}$, propiciando durante el experimento un recambio $(R)$ de $0.85 \mathrm{R} /$ hora o $20 \mathrm{R} /$ día. Las unidades de cultivo se cubrieron con malla polisombra para evitar que los animales saltaran fuera de los tanques (Figura 3B).

Traslado de animales. Los peces se trasladaron desde la estación Intiyaco hasta el laboratorio ubicado en la Universidad de Nariño, para ello se sometió a los animales a un período de ayuno de 24 horas, posteriormente se empacaron en grupos de 15 ejemplares en bolsas plásticas con 10 litros de agua y oxígeno para su transporte y su posterior aclimatación.

Aclimatación y siembra. Las bolsas con los animales se introdujeron en las unidades de cultivo durante 15 minutos, luego se abrieron y se mezcló el agua de la bolsa con la del SRA con el fin de estabilizar progresivamente los valores de $\mathrm{pH}, \mathrm{OD}$, temperatura y alcalinidad. Como tratamiento profiláctico se agregó a cada bolsa $15 \mathrm{~g}$ de sal marina por un lapso de 15 minutos. Los animales aclimatados se liberaron en cada unidad experimental dejándolos por un periodo de adaptación de 15 días, tiempo en el cual se suministró alimento preparado con florfenicol.

Muestreo de los animales. Los muestreos se realizaron cada 15 días, se utilizaron 12 animales que representaron el $44 \%$ de la población total de cada unidad experimental. Para facilitar la manipulación de los peces con el fin de registrar peso y talla los especímenes fueron tranquilizados con una solución de quinaldina comercial en una
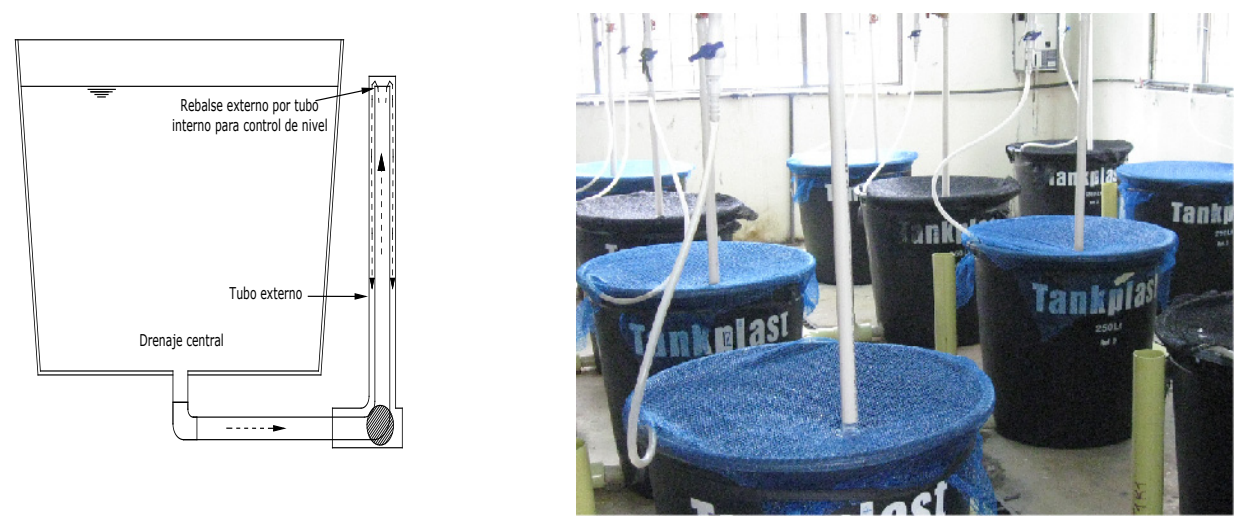

Figure 3. Tank with central drain and external lateral overflow pipe (A); laboratory culture units (B). 
Feeding. The food provided was based on a commercial concentrate with $48 \%$ of crude protein, $2.800 \mathrm{kcal} / \mathrm{kg}$ of EM in granules 3.5 $\mathrm{mm}$ in diameter. The amount of food to be supplied was calculated taking into account the feed conversion, condition factor, temperature and population for each experimental unit. The calculated ration was distributed in three meals supplied at 7 a.m., 11 a.m. and 6 p.m. recording the relevant data in a logbook.

Water quality monitoring. The methodologies recommended by APHA, AWWA \& WEF (13) were adopted for the measurement of water quality parameters monitored. The parameters studied were measured at the entry and exit of the treatment system of the ARS, i.e. in the mixed and homogenized effluent of culture units and at the exit of the biofilter. Eight samples were taken of $\mathrm{pH}$ values -Electrometric method: APHA, AWWA and WEF (1998) No. 4500- $\mathrm{H}^{+}$B-, temperature -Direct reading: APHA, AWWA and WEF (1998) No. 2550 B-, dissolved oxygen (DO) -Sodium azide modified winkler: APHA, AWWA and WEF (1998) No. 4500-O C-, total ammoniacal nitrogen (NAT) -Colorimetric method - APHA, AWWA and WEF (1998) No. 4500 D-, nitrites -Colorimetric method - APHA, AWWA and WEF (1998) No. 4500- $\mathrm{NO}_{2}$ - and nitrates - Cadmium reduction method: APHA, AWWA and WEF (1998) No. 4500- $\mathrm{NO}_{3} \mathrm{I}-$; conductivity values were measured three times -Electrometric method: APHA, AWWA and WEF (1998) No. 2510-, hardness - Titrimetric method: APHA, AWWA and WEF (1998) No. 2340 C-, salinity - Electrical conductivity method: APHA, AWWA and WEF (1998) No. 2520 B-, as well as the analysis of total suspended solids (TSS) at the entry and exit of the conventional sedimentation tank Gravimetric method: APHA, AWWA and WEF (1998) No. 2540 D-. A portable pH meter EC10 model $50050 \mathrm{HACH}$, a conductivity meter $\mathrm{HACH}$ model CO 150 and a colorimeter HACH DR 700 were used for the measurement of parameters.

System water replacements. The water in the ARS was partially and periodically replaced as follows: every 8 days $10 \%$ of the biofilter volume and $100 \%$ of the settler volume, every fortnight $80 \%$ of each experimental unit. Such substitutions were carried out with previously dechlorinated water; in addition, siphoning was performed to the settler every week for the evacuation of the sediment solids.

\section{Variables evaluated.}

Weight increase (IP). Twenty percent of the animals of each replication were sampled at the beginning of the experiment and then every 15 days to determine the weight gain. The variable concentración de $5.0 \mathrm{mg} / \mathrm{l}$, la actividad se realizó en un recipiente plástico con 12 litros de capacidad y el tiempo de exposición fue de 2 a 3 minutos. Finalmente a los individuos muestreados se les realizó un baño profiláctico con permanganato de potasio a una concentración de $10 \mathrm{ppm}$.

\begin{abstract}
Alimentación. La alimentación proporcionada fue a base de concentrado comercial con $48 \%$ de proteína bruta, $2.800 \mathrm{kcal} / \mathrm{kg}$ de EM, en presentación de gránulos de $3.5 \mathrm{~mm}$ de diámetro. La cantidad de alimento a suministrar se calculó teniendo en cuenta la conversión alimenticia, el factor de condición, la temperatura y la población por cada unidad experimental. La ración calculada se distribuyó en tres comidas suministradas a las 7 a.m., 11 a.m. y 6 p.m. registrando los datos correspondientes en una bitácora.
\end{abstract}

Monitoreo de la calidad del agua. Para la medición de los parámetros de calidad del agua monitoreados se adoptaron las metodologías recomendadas por APHA, AWWA \& WEF (13). Los parámetros estudiados se midieron a la entrada y salida del sistema de tratamiento del SRA; es decir, en el efluente mezclado y homogenizado de las unidades de cultivo y a la salida del biofiltro. Se realizaron 8 muestreos de los valores de $\mathrm{pH}$ Método electrométrico: APHA, AWWA, WEF (1998) $\mathrm{n}^{\circ}$ 4500- $\mathrm{H}^{+} \mathrm{B}-$, temperatura -Lectura directa: APHA, AWWA, WEF (1998) n 2550 B-, oxígeno disuelto (OD)- Winkler modificado azida de sodio: APHA, AWWA, WEF (1998) n 4500-O C-, nitrógeno amoniacal total (NAT) -Método colorimétrico APHA, AWWA, WEF (1998) n० 4500 D-, nitritos -Método colorimétrico - APHA, AWWA, WEF (1998) no 4500- $\mathrm{NO}_{2}-$ y nitratos -Método reducción de cadmio: APHA, AWWA, WEF (1998) Nro. 4500$\mathrm{NO}_{3} \mathrm{I}-$; se midió en tres oportunidades los valores de conductividad -Método electrométrico: APHA, AWWA, WEF (1998) Nro. 2510-, dureza -Método titrimétrico: APHA, AWWA, WEF (1998) Nro. 2340 C-, salinidad -Método de conductividad eléctrica: APHA, AWWA, WEF (1998) Nro. 2520 B-, así como el análisis de sólidos suspendidos totales (SST) a la entrada y salida del sedimentador convencional -Método Gravimétrico: APHA, AWWA, WEF (1998) Nro. 2540 D-. Para la medición de los parámetros se utilizó un pHmetro portátil EC10 modelo 50050 $\mathrm{HACH}$, un conductivímetro $\mathrm{HACH}$ modelo $\mathrm{CO} 150$ y un colorímetro HACH DR 700.

Recambios del sistema. Al SRA se le realizaron sustituciones de agua parcial y periódicamente de la siguiente manera: cada 8 días un $10 \%$ del volumen del biofiltro y $100 \%$ del sedimentador; cada quince días un $80 \%$ de cada unidad experimental. Tales sustituciones se efectuaron con agua previamente declorinada; adicionalmente, al sedimentador se le realizó 
was calculated based on the equation 1 :

$I P=P f-P i[1]$

Where $\mathrm{Pf}$ is the final weight and $\mathrm{Pi}$ the initial weight in each period.

Length increase (IL). Twenty percent of the animals of each replication were also sampled to determine this variable, under the same conditions for the determination of IP. The increase in length was calculated using equation 2:

$I L=L f-L i[2]$

Where $L f$ is the final length and $L i$ the initial length in each sample.

Mortality percentage (M\%). The amount of fish that died during the study period was calculated using equation 3 :

$$
M(\%)=(P I-P F) * 100 / P I \text { [3] }
$$

Where PI and PF are the initial and final populations respectively.

Feed conversion (CA). It is estimated using equation 4 :

$C A=A S / I P[4]$

Where AS corresponds to the food supplied and IP the weight increase.

\section{RESULTS}

Water quality parameters. In general terms, water quality parameters in culture units remained within the allowable and recommendable ranges for the cultivation of the species. Table 1 shows the most important values related to the behavior of each parameter.

Table 1. Minimum, average and maximum values of the water quality parameters monitored.

\begin{tabular}{lccc}
\hline \multicolumn{1}{c}{ Parameter } & Minimum & Average & Maximum \\
\hline $\mathrm{pH}$ & 6.34 & 6.90 & 7.41 \\
Temperature $\left({ }^{\circ} \mathrm{C}\right)$ & 15.40 & 16.10 & 17.20 \\
Dissolved oxygen $(\mathrm{mg} / \mathrm{l})$ & 3.90 & 6.09 & 7.10 \\
Hardness $\left(\mathrm{mg} / \mathrm{l}\right.$ of $\left.\mathrm{CaCO}_{3}\right)$ & 21.50 & 30.78 & 44.80 \\
Alkalinity $(\mathrm{mg} / \mathrm{l})$ & 4.85 & 6.06 & 7.26 \\
Conductivity $(\mu \mathrm{mho} / \mathrm{cm})$ & 211 & 265 & 295 \\
\hline
\end{tabular}

cada media semana un sifoneo para evacuación de los sólidos sedimentados.

\section{Variables evaluadas.}

Incremento de peso (IP). Para determinar la ganancia de peso se muestreó el $20 \%$ de los animales de cada réplica, al inicio del experimento y luego cada 15 días. La variable se calculó con base en la ecuación 1 :

$I P=P f-P i[1]$

Donde Pf fue el peso final y $\mathrm{Pi}$ el peso inicial de cada periodo.

Incremento de longitud (IL). Para determinar esta variable se muestreó también el $20 \%$ de cada réplica, en las mismas ocasiones realizadas para la determinación de IP. El incremento de longitud se calculó por medio de la ecuación 2 :

$$
I L=L f-L i \quad[2]
$$

Donde Lf fue la longitud final y Li la inicial en cada muestreo.

Porcentaje de mortalidad (M\%). La cantidad de peces que murieron durante el periodo de estudio se calculó mediante la ecuación 3:

$$
M(\%)=(P I-P F) * 100 / P I \text { [3] }
$$

Donde PF y PI fueron las poblaciones final e inicial, respectivamente.

Conversión alimenticia (CA). Se estimó mediante la ecuación 4 :

$$
C A=A S / I P[4]
$$

Donde AS correspondió al alimento suministrado e IP el incremento de peso.

\section{RESULTADOS}

Parámetros de calidad del agua. En términos generales, los parámetros de calidad del agua en las unidades de cultivo se mantuvieron dentro de los rangos permisibles y recomendables para el cultivo de la especie. La tabla 1 presenta los valores más importantes relativos al comportamiento de cada parámetro.

Nitrógeno amoniacal total (NAT). Se registraron altas concentraciones de NAT, con valores medios a la entrada y salida del biofiltro de $4.82 \mathrm{mg} / \mathrm{L}$ y $4.47 \mathrm{mg} / \mathrm{L}$ respectivamente. 
Total ammoniacal nitrogen (TAN). High concentrations of TAN were recorded, with average values of $4.82 \mathrm{mg} / \mathrm{L}$ and $4.47 \mathrm{mg} / \mathrm{L}$ at the entry and exit of the biofilter, respectively.

Nitrites. Based on the values measured, the average concentration calculated at the entry of the biofilter was $0.53 \mathrm{mg} / \mathrm{l}$ and the average value calculated at the exit was $0.61 \%$.

Nitrates. The average nitrate concentrations calculated in the influent and effluent of the biofilter were $2.77 \mathrm{mg} / \mathrm{l}$ and $2.60 \mathrm{mg} / \mathrm{l}$, respectively.

\section{Efficiencies of the treatment system.}

Removal of solids. An inflow of $36 \mathrm{l} / \mathrm{min}$ was regulated in the conventional sedimentation tank, representing a hydraulic retention time (HRT) for the settler of 14.51 minutes and a surface application rate (SAR) of $71.5 \mathrm{~m}^{3} /$ $\mathrm{m}^{2} / \mathrm{d}$. Based on the results measured, it was determined that the efficiency in the removal of total suspended solids by the system was $31 \%$.

Biofilter performance. The submerged and upflow biofilter with an inflow of $36 \mathrm{l} / \mathrm{min}$, a HRT of 20.83 minutes and a surface application rate of $117.4 \mathrm{~m}^{3} / \mathrm{m}^{2} / \mathrm{d}$ favored the nitrification processes of the ammonia produced in the system and reported an average removal TAN percentage of $9.47 \%$.

Degasser. The degassing for the release of $\mathrm{CO}_{2}$ and the increase in dissolved oxygen of the system reported an average percentage increase in the DO concentration in water of $6.5 \%$.

\section{Productive Variables.}

Weight increase. On average, the initial weight in the culturing phase was $32.45 \pm 2.20 \mathrm{~g}$ and the final weight obtained after 75 days of study was $111.81 \pm 8.79 \mathrm{~g}$; the average values obtained in six surveys are shown in Figure 4. Average weight increases calculated were $1.06 \mathrm{~g} /$ day and 15.90 g/fortnight.

Length increase. On average, the initial length in the culturing phase was $14.22 \pm 0.46 \mathrm{~cm}$ and the final size obtained after 75 days was $20.50 \pm 0.37 \mathrm{~cm}$, as shown in figure 5 .

Feed conversion. On average, feed conversion during the phase analyzed was $1.82: 1$, with a maximum value of $2.91: 1$ and $1.0: 1.0$ as minimum value.
Nitritos. Con base en los valores medidos, la concentración media calculada a la entrada del biofiltro fue de $0.53 \mathrm{mg} / \mathrm{l}$ y el valor medio calculado a la salida fue de 0.61 .

Nitratos. Las concentraciones medias de nitratos calculadas en el afluente y efluente del biofiltro fueron de $2.77 \mathrm{mg} / \mathrm{l}$ y $2.60 \mathrm{mg} / \mathrm{l}$ respectivamente.

\section{Eficiencias del sistema de tratamiento.}

Remoción de sólidos. En el sedimentador convencional se reguló un caudal de ingreso de $36 \mathrm{l} / \mathrm{min}$, representando para el sedimentador un tiempo de retención hidráulica (TRH) de 14.51 minutos y una tasa de aplicación superficial (TAS) de $71.5 \mathrm{~m}^{3} / \mathrm{m}^{2} / \mathrm{d}$. Con base en los resultados medidos se determinó que la eficiencia en la remoción de los sólidos suspendidos totales por parte del sistema fue del $31 \%$.

Desempeño del biofiltro. El biofiltro de lecho sumergido y flujo ascendente con un caudal de ingreso de $36 \mathrm{l} / \mathrm{min}$, un TRH de 20.83 minutos y una tasa de aplicación superficial de $117.4 \mathrm{~m}^{3} /$ $\mathrm{m}^{2} / \mathrm{d}$ propició los procesos de nitrificación del amoníaco producido en el sistema y reportó en promedio un porcentaje de remoción del NAT de $9.47 \%$.

Desgasificador. La desgasificación para liberación del $\mathrm{CO}_{2}$ y el aumento de oxígeno disuelto del sistema reportaron un valor medio de incremento porcentual de la concentración de OD en el agua del $6.5 \%$.

\section{Variables Productivas.}

Incremento de peso. En promedio el peso inicial de la fase de levante fue de $32.45 \pm 2.20 \mathrm{~g}$ y el peso final que se obtuvo después de 75 días de estudio fue de $111.81 \pm 8.79 \mathrm{~g}$; los valores medios obtenidos en los seis muestreos se presentan en la figura 4. Los incrementos de peso promedio calculados fueron de $1.06 \mathrm{~g} /$ día y de $15.90 \mathrm{~g} /$ quincena.

Incremento de longitud. En promedio la longitud inicial de la fase de levante fue de $14.22 \pm 0.46 \mathrm{~cm}$ y la talla final que se obtuvo después de los 75 días fue de $20.50 \pm 0.37 \mathrm{~cm}$, tal como lo ilustra la figura 5 .

Conversión alimenticia. En promedio la conversión alimenticia durante la fase analizada fue de 1.82:1; con valor máximo de 2.91:1 y como valor mínimo 1.0:1.0. 


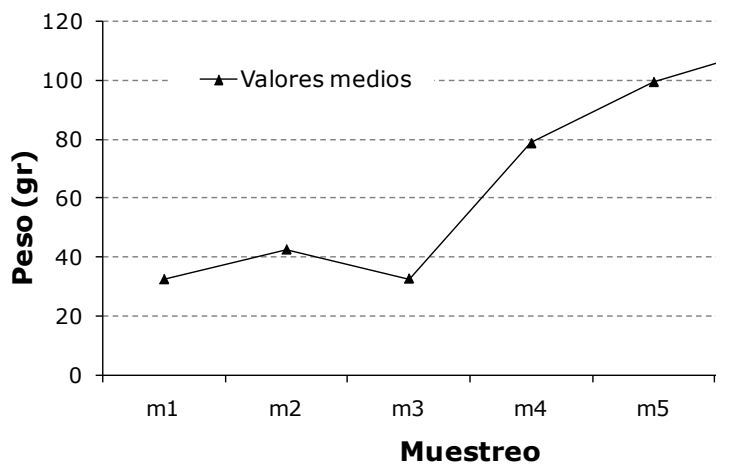

Figure 4. Curve of average weights sampled during the study.

Mortality. During the research, a total mortality of $4.9 \%$ was recorded in the study period, mainly in the final stage. This situation could occur due to higher biomass per cubic meter, which increased the DO consumption and ammonium production with the consequent deterioration in water quality.

Biomass production. The initial biomass was on average $3.49 \mathrm{~kg} / \mathrm{m}^{3}$ for each experimental unit, increasing up to a maximum value of $12.08 \mathrm{~kg} / \mathrm{m}^{3}$.

\section{DISCUSSION}

During the experiment, $\mathrm{pH}$ fluctuated within the ranges recommended for aquaculture (11), the cultivation of rainbow trout (14) and the sound performance of the fixed bed biofilter (15).

Water temperatures recorded in the ARS were within the optimal range for the species as recommended by Timmons and Ebeling (11), providing favorable conditions for growth and development.

The average DO concentration stood near the lower range recommended for the proper growth of trout (11) and above the minimum value recommended for systems with fixed bed biofilters (15).

During the experiment, hardness values were lower than $100 \mathrm{mg} / \mathrm{l}$ recommended for aquaculture (11), even though they were above the minimum acceptable value of $20 \mathrm{mg} / \mathrm{l}$ for trout (14). Alkalinity, which exerts a marked influence on the biochemical processes developed in the ARS - such as nitrification, which consumes alkalinity (16) - decreased gradually with the passage of time and recorded values lower than the optimum for the cultivation of the species (14), therefore it is recommended to maintain their levels stable and

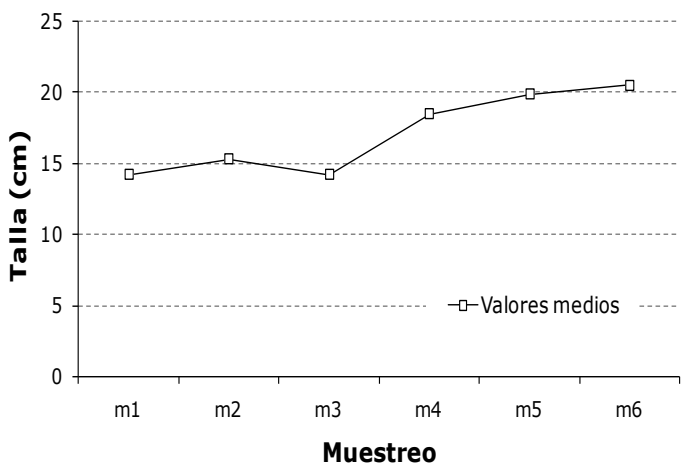

Figure 5. Longitudinal growth curve.

Mortalidad. Durante la investigación se registró una mortalidad total del $4.9 \%$ en el periodo del estudio, principalmente en la etapa final. Dicha situación se pudo presentar debido a la mayor biomasa por metro cúbico, que incrementó el consumo de OD y la producción de amonio con el consiguiente deterioro de la calidad de agua.

Producción de biomasa. La biomasa inicial fue en promedio de $3.49 \mathrm{~kg} / \mathrm{m}^{3}$, para cada unidad experimental, incrementándose hasta un valor máximo de $12.08 \mathrm{~kg} / \mathrm{m}^{3}$.

\section{DISCUSIÓN}

Durante el experimento el pH osciló dentro de los rangos recomendados para acuacultura (11), para el cultivo de trucha arco iris (14) y para el buen desempeño del biofiltro de lecho fijo (15).

Las temperaturas del agua registradas en el SRA se enmarcaron en el rango óptimo para la especie recomendado por Timmons y Ebeling (11), propiciando las condiciones favorables para el crecimiento y desarrollo.

La concentración media del OD se localizó cerca del rango inferior recomendado para el adecuado crecimiento de la trucha (11) y por encima del valor mínimo recomendado para sistemas con biofiltros de lecho fijo (15).

Durante el experimento los valores de dureza fueron menores a los $100 \mathrm{mg} / \mathrm{l}$ recomendados para acuacultura (11), aunque estuvieron por encima del mínimo valor aceptable de $20 \mathrm{mg} / \mathrm{l}$ para trucha (14). La alcalinidad, que ejerce marcada influencia en los procesos bioquímicos desarrollados en los SRA -como la nitrificación, que consume alcalinidad (16)- disminuyó progresivamente con el transcurrir del tiempo y siempre registró valores inferiores a los óptimos para el cultivo de la especie (14), por ello es 
prevent possible effects on the biofiltration system in subsequent experiences.

The average value for conductivity is within the normal ranges for natural fresh water from 20 to $1000 \mu \mathrm{mho} / \mathrm{cm}$ (17), providing conditions similar to those for the development of the species in nature.

While TAN concentrations in the ARS exceeded the maximum value of $1.0 \mathrm{mg} / \mathrm{l}$ recommended for trout growing $(11,18)$, there were no deaths that could be attributed to such situation since these concentrations together with $\mathrm{pH}$ values close to neutrality and the low temperatures registered ensured that ammonia was practically present in ionized form (9). Differences in concentrations at the entry and exit of the treatment system showed the nitrification process.

The highest concentrations of nitrites in the effluent of the biofilter, as compared to those recorded in its affluent, ratify the development of the nitrification process in this unit, as the increase in concentration and the decrease in total ammoniacal nitrogen values indicate the transformation of ammonia into nitrites. Furthermore, the values for nitrates were within the ranges recommended for aquaculture (11) and in particular for trout (14).

In Colombia, Standard RAS (19) stipulates that for high rate trickling filters, removal efficiencies of $\mathrm{NH}_{3}-\mathrm{N}$ for domestic wastewater commonly range between 8 and $15 \%$ for surface application rates in plastic mediums between 14 and $84.2 \mathrm{~m}^{3} /$ $\mathrm{m}^{2} / \mathrm{d}$. The relatively low removal value obtained from the experiment may be due to the type of substrate used for the formation of the biofilm of nitrifying bacteria - smooth recycled PVC pipe segments with a diameter of $1 / 2$ " - represented a smaller contact surface to that produced by other support mediums, although the material used in this research is much cheaper and environmentally friendly due to its recycled condition. Al-Hafedh et al (20) investigated the use of various plastic support mediums, such as segments of corrugated PVC pipes in trickling biofilters for tilapia culture in ARS under a HRT of 112.5 minutes and reported a NAT removal efficiency in the order of $25.5 \%$; moreover, Lekang and Kleppe (21) reported efficiencies exceeding $40 \%$ for trickling biofilters with surface application rates of $91 \mathrm{~m}^{3} / \mathrm{m}^{2} / \mathrm{d}$ with granular support mediums in expanded clay and synthetic mediums with a specific surface area much higher than that offered by the pipe segments used in this experiment.

In terms of design parameters and the performance of conventional settlers for the treatment of wastewater, Spellman (22) reported SS removal recomendable en posteriores experiencias mantener sus niveles estables y evitar los posibles efectos en el sistema de biofiltración.

El valor medio de la conductividad se encontró dentro de los rangos normales para agua dulce natural de 20 a $1000 \mu \mathrm{mho} / \mathrm{cm}$ (17), proporcionando condiciones semejantes a las del desarrollo de la especie in natura.

Pese a que las concentraciones de NAT registradas en el SRA superaron al valor máximo de $1.0 \mathrm{mg} / \mathrm{l}$ recomendado para cultivo de trucha $(11,18)$, no hubo mortalidades que se pudieran atribuir a tal situación ya que dichas concentraciones junto con los valores de $\mathrm{pH}$ cercanos a la neutralidad y a las bajas temperaturas registradas garantizaron que el amoníaco se presentó prácticamente en la forma ionizada (9). Las diferencias de concentraciones a la entrada y salida del sistema de tratamiento evidenciaron el proceso de nitrificación.

Las mayores concentraciones de nitritos en el efluente del biofiltro, con relación a las registradas en su afluente, ratifican el desarrollo del proceso de nitrificación en esta unidad, pues el aumento de su concentración y la disminución de los valores del nitrógeno amoniacal total indican la transformación del amoniaco en nitritos. Por su parte, los valores de nitratos se encontraron dentro de los rangos recomendables para acuacultura (11) y en particular para trucha (14).

En Colombia, la Norma RAS (19) estipula que para filtros percoladores de alta tasa las eficiencias de remoción de $\mathrm{NH}_{3}-\mathrm{N}$ para aguas residuales domésticas comúnmente oscilan entre el 8 y el $15 \%$ para tasas de aplicación superficial en medios plásticos entre 14 y $84.2 \mathrm{~m}^{3} / \mathrm{m}^{2} / \mathrm{d}$. El relativamente bajo valor de remoción obtenido en el experimento puede deberse a que el tipo de sustrato que sirvió para la formación de la biopelícula de bacterias nitrificantes -segmentos reciclados de tubos de PVC lisos de $1 / 2$ de diámetro"representó una superficie de contacto menor a la que producen otros medios soporte, aunque el material utilizado en esta investigación es mucho más económico y ambientalmente recomendable por su condición de reciclaje. Al-Hafedh et al (20) investigaron el uso de diversos medios soporte plásticos, tales como segmentos de tubos de PVC corrugado en biofiltros percoladores para cultivo de tilapia en SRA bajo un TRH de 112,5 minutos y reportaron una eficiencia de remoción del NAT del orden del 25,5\%; por su parte, Lekang y Kleppe (21) han reportado eficiencias superiores al $40 \%$ para biofiltros percoladores con tasas de aplicación superficial de $91 \mathrm{~m}^{3} / \mathrm{m}^{2} / \mathrm{d}$ con medios de soporte granulares en arcilla expandida y medios sintéticos con superficie específica muy superiores a la ofrecida por los segmentos de tubería utilizados en este experimento. 
efficiencies between 40 and $60 \%$ for units with SAR between 12.2 and $48.8 \mathrm{~m}^{3} / \mathrm{m}^{2} /$ day and HRT between 1.5 and 2.5 hours, Romero (23) recommended a SAR between 24 and $33 \% \mathrm{~m} /$ day and HRT between 1 and 2 hours for the design of primary sedimentation tanks to obtain a removal of SS between 50 and $70 \%$, and Title $\mathrm{E}$ of the Standard RAS (19) defined an interval between $50 \%$ and $65 \%$ as the range of efficiencies for the removal of SS in primary sedimentation tanks with surface overflow rates of $33 \mathrm{~m}^{3} / \mathrm{m}^{2} / \mathrm{d}$ and a minimum HRT of one hour.

In previous cases, the SAR recommended are lower and the HRT greater than those applied in the settler used in this research, which explains the lower removal efficiency of TSS in relation to the values expected according to the literature. However, the settler was within the design parameters recommended by Lekang (24) for aquaculture systems with SAR between 24 and $120 \mathrm{~m}^{3} / \mathrm{m}^{2} / \mathrm{d}$ and HRT close to the lower value suggested of 15 to 40 minutes; additionally, the settler operated under the SAR range recommended by Timmons and Ebeling (11) for this type of units with a SAR from 24 to $94 \mathrm{~m}^{3} / \mathrm{m}^{2} / \mathrm{d}$ to obtain TSS removal efficiencies between 40 and $60 \%$.

The removal of $31 \%$ of the TSS produced by system could obey to the low HRT of the treatment unit, the relatively high surface application rate, and the limited distribution uniformity of the flow produced by the thick wall weir used as input device to the settler. For subsequent experiences, it will be necessary to adapt an inlet system to the sedimentation unit such as for example a perforated screen that favors a homogeneous affluent flow and thus optimize the volume used for the removal of solids. The implementation of this type of devices allows the optimization of the volume allocated to the sedimentation of particles, prevents the presence of dead zones or preferential flows and improves the performance of these treatment units; while it is true that the system managed to maintain TSS levels below $80 \mathrm{mg} / \mathrm{L}$, the maximum standard value recommended for aquaculture (11) exceeded that required for trout, where water with low turbidity is recommended for its cultivation (14).

During the research, DO levels reported upon entry to culture units - provided by the degassing device by hydraulic drop - remained above $6.0 \mathrm{mg} / \mathrm{l}$, hence conforming to the values recommended for trout (11), (14). In order to obtain greater efficiencies in the transfer of atmospheric oxygen from free-flow hydraulic systems, it is possible to use another natural ventilation mechanism such as rectangular and especially triangular weirs, whose high efficiency has been tested by Baylar
En cuanto a los parámetros de diseño y al desempeño de sedimentadores convencionales para el tratamiento de aguas residuales, Spellman (22) reporta eficiencias de remoción de SS entre el 40 y el $60 \%$ para unidades con TAS de entre 12.2 y $48.8 \mathrm{~m}^{3} / \mathrm{m}^{2} /$ día y TRH entre 1.5 y 2.5 horas, Romero (23) recomienda para el diseño de sedimentadores primarios TAS entre 24 y 33 $\mathrm{m} /$ día y TRH entre 1 y 2 horas para obtener remociones de SS entre 50 y $70 \%$ y el Título E de la Norma RAS (19) define como rango de eficiencias de remoción de SS entre el 50 y $65 \%$ para sedimentadores primarios con tasas de desbordamiento superficial de $33 \mathrm{~m}^{3} /$ $\mathrm{m}^{2} / \mathrm{d}$ y TRH de mínimo una hora.

En los anteriores casos, las TAS recomendadas son menores y los TRH mayores a los otorgados al sedimentador utilizado en esta investigación, lo que explica la menor eficiencia de remoción de SST con relación a los valores esperados según la literatura. Sin embargo, el sedimentador se estuvo dentro de los parámetros de diseño recomendados por Lekang (24) para sistemas acuícolas con TAS entre 24 y 120 $\mathrm{m}^{3} / \mathrm{m}^{2} /$ día y con TRH cercano al valor inferior sugerido de 15 a 40 minutos; adicionalmente el sedimentador operó bajo el rango de TAS recomendado por Timmons y Ebeling (11) para este tipo de unidades en SRA de 24 a $94 \mathrm{~m}^{3} / \mathrm{m}^{2} /$ día para obtener eficiencias de remoción de SST entre el 40 y $60 \%$.

La remoción del $31 \%$ de los SST producidos por el sistema pudo obedecer al bajo TRH de la unidad de tratamiento; la relativamente alta tasa de aplicación superficial; y la limitada uniformidad de distribución del flujo producida por el vertedero de pared gruesa utilizado como dispositivo de entrada al sedimentador. Para experiencias posteriores será necesario adecuar un sistema de ingreso a la unidad de sedimentación como por ejemplo una pantalla perforada que propicie un flujo afluente homogéneo y así optimice el volumen utilizado para remoción de los sólidos. La implementación de este tipo de dispositivos permiten la optimización del volumen destinado a la sedimentación de las partículas, evita la presencia de zonas muertas o flujos preferenciales y mejora el desempeño de dichas unidades de tratamiento; pues si bien es cierto el sistema logró mantener los niveles de SST por debajo de los $80 \mathrm{mg} / \mathrm{L}$, valor máximo estándar recomendado para acuacultura (11) pudo superar los requeridos por la trucha, para cuyo cultivo se recomiendan aguas con baja turbidez (14).

Durante la investigación los niveles del OD registrados al ingreso de las unidades de cultivo -proporcionados por el desgasificador mediante caída hidráulicapermanecieron por encima de $6.0 \mathrm{mg} / \mathrm{l}$, cumpliendo de esta manera con los valores recomendados para trucha (11), (14). Para efectos de obtener mayores eficiencias de transferencia del oxígeno atmosférico a partir de sistemas hidráulicos a flujo libre podría optarse por otro mecanismo de aireación natural 
and Bagatur (25) and tried in hydraulic recirculating systems by Baylar et al (26).

The best results regarding weight increase occurred between sampling 3 and 4 . The growth curve raised $83 \%$ of the time recorded in the study; the decline in values between samplings 2 and 3 can be explained by the variety of animal weights within the population sampled, which could affect the average value.

As reference data, the weight gain for trout at a temperature of $16^{\circ} \mathrm{C}$ is $0.92 \mathrm{~g} /$ day or $28.1 \mathrm{~g} /$ month (11), values lower than those recorded in this study were where increments of $1.13 \mathrm{~g} /$ day and $34.47 \mathrm{~g} /$ month were obtained. According to Observatorio de Agrocadenas de Colombia (27), the production cycle for trout is 9.75 months. Usually, its cultivation begins with fingerlings of 2 $\mathrm{g}$ and ends with animals with an average weight of $307 \mathrm{~g}$, for an increase of $1.04 \mathrm{~g} /$ day and $31.32 \mathrm{~g} /$ month, values surpassed by this study in about $2 \%$.

The daily increase of size calculated from the data reported was $0.084 \mathrm{~cm} /$ day for a periodic increment of $1.26 \mathrm{~cm} /$ fortnight. The best results in terms of increased size occurred in samplings 3 and 4 showing a steeper slope in Figure 5 . The effect of the diversity in the size of animals measured in the third sampling was once again evidenced.

The longitudinal growth of trout is directly related to the temperature of the water, which in this study was on average at $19.99^{\circ} \mathrm{C}$; by applying the growth formula proposed by Timmons and Ebeling (11), animals should have a minimum growth of 0.088 $\mathrm{cm} /$ day or $2.63 \mathrm{~cm} /$ month; in this research the growth calculated was $0.084 \mathrm{~cm} /$ day or $2.52 \mathrm{~cm} /$ month, $4.5 \%$ lower than those expected according to the reference quoted.

The average production cycle of trout is 9.75 months (27), starting with $5 \mathrm{~cm}$ fingerlings and ending with animals of $29 \mathrm{~cm}$ in length, for an increase in size of $0.082 \% \mathrm{~cm} /$ day or $2.46 \mathrm{~cm} /$ month, values exceeded in this study by $7.3 \%$.

The more favorable values for feed conversion are similar to those reported by Arredondo et al (28) and by van Rijn (29) in ARSs. The variability observed in feed conversion can be explained by the progressive increase in biomass and the increased load per unit volume in each experimental unit throughout the study, which could cause stress in fish, increased DO consumption and the eventual deterioration of certain water quality parameters. This reduces the efficiency of animals to convert balanced food into biomass, since part of the protein supplied could be used in basal metabolism processes and not in the construction of tissues. como los vertederos rectangulares y especialmente los triangulares, cuya alta eficiencia ha sido probada por Baylar y Bagatur (25) y ensayada en sistemas de recirculación hidráulica por Baylar et al (26).

Los mejores resultados de incremento de peso se presentaron entre el muestreo 3 y 4 . La curva de crecimiento fue ascendente el $83 \%$ del tiempo registrado en el estudio; el descenso de valores entre el muestreo 2 y 3 se explica por la variedad de pesos de los animales dentro de la población muestreada, lo que pudo afectar el valor promedio.

Como datos de referencia, la ganancia de peso de la trucha a una temperatura de $16^{\circ} \mathrm{C}$ es de $0.92 \mathrm{~g} /$ día o de $28.1 \mathrm{~g} / \mathrm{mes}$ (11), valores inferiores a los registrados en este estudio donde se obtuvieron incrementos de $1.13 \mathrm{~g} /$ día y $34.47 \mathrm{~g} / \mathrm{mes}$. De acuerdo con el Observatorio de Agrocadenas de Colombia (27), el ciclo de producción de la Trucha es de 9.75 meses. Generalmente su cultivo inicia con alevinos de $2 \mathrm{~g}$ y finaliza con animales con peso promedio de $307 \mathrm{~g}$, para un incremento de $1.04 \mathrm{~g} /$ día y $31.32 \mathrm{~g} / \mathrm{mes}$, valores superados por este estudio en cerca del $2 \%$.

El incremento de talla diario calculado a partir de los datos registrados fue de $0.084 \mathrm{~cm} /$ día, para un incremento periódico de $1.26 \mathrm{~cm} /$ quincenal. Los mejores resultados en cuanto al aumento de talla se presentaron entre los muestreos 3 y 4 donde se observa una pendiente más pronunciada en la figura 5. Nuevamente se puso en evidencia el efecto de la diversidad de tallas de los animales medidos en el tercer muestreo.

El crecimiento longitudinal de la trucha está directamente relacionado con la temperatura del agua, que en esta investigación presentó un promedio de $16.09^{\circ} \mathrm{C}$; aplicando la fórmula de crecimiento propuesta por Timmons y Ebeling (11), los animales debían tener un crecimiento mínimo de $0.088 \mathrm{~cm} /$ día o $2.63 \mathrm{~cm} / \mathrm{mes}$; en la presente investigación los crecimientos calculados fueron de $0.084 \mathrm{~cm} /$ día o $2.52 \mathrm{~cm} / \mathrm{mes}$, inferiores en un $4,5 \%$ a los esperables según la referencia citada.

El ciclo promedio de producción de trucha es de 9.75 meses (27), iniciando con alevinos de $5 \mathrm{~cm}$ y finalizando con animales de $29 \mathrm{~cm}$ de longitud, para un incremento de talla de $0.082 \mathrm{~cm} /$ día o de $2.46 \mathrm{~cm} /$ mes, valores superados por este estudio en un $7.3 \%$.

Los valores más favorables de la conversión alimenticia se asemejan a los reportados por Arredondo et al (28) y por van Rijn (29) en SRA. La variabilidad observada en la conversión alimenticia se puede explicar debido al incremento progresivo de la biomasa y mayor carga por unidad de volumen en cada unidad experimental a lo largo del estudio; lo que pudo provocar estrés en los peces, mayor consumo de OD y el eventual 
In conclusion, the water treatment system evaluated allowed maintaining physicochemical water quality parameters within the ranges required by the culturing phase of rainbow trout. Wastewater treatment units allowed to remove $30 \%$ of TSS (conventional sedimentation tank), allowed a 9\% removal of TAN (biofiltration unit), and increased dissolved oxygen to the final effluent in $6 \%$ (degasser).

The productive variables analyzed: weight and size increase, feed conversion, mortality and production; were within the normal values for the production of the species cultivated. The recirculating system evaluated commenced with a load of $3.5 \mathrm{~kg} / \mathrm{m}^{3}$ and ended with a load of $12.1 \mathrm{~kg} /$ $\mathrm{m}^{3}$, indicating an increase in biomass of $345 \%$. The mortality percentage recorded during the entire study period was $4.9 \%$.

\section{Acknowledgements}

To the VIPRI of University of Nariño, to Professor Roberto Salazar Cano and the students of the Aquaculture Production Engineering Program: Karen Larrañaga; Viviana Cardenas; Carlos Caicedo; Luis Enriquez; Diego Miramac; Adriana Arce; Silvia Bolaños; Felix Jojoa; Lorena Ortega; Diana Beltran and Nataly Sarasty. deterioro de algunos parámetros de calidad de agua. Ello reduce la eficiencia de los animales para convertir el balanceado en biomasa, ya que parte de la proteína suministrada pudo ser utilizada en procesos de metabolismo basal y no en la construcción de tejidos.

En conclusión, el sistema de tratamiento del agua evaluado permitió mantener los parámetros físicoquímicos de la calidad de agua dentro de los rangos requeridos por la fase de levante de la Trucha arco iris. Las unidades de tratamiento del agua residual permitieron la remoción de $30 \%$ de los SST (sedimentador convencional), proporcionaron la remoción del NAT en un 9\% (unidad de biofiltración), e incrementaron el oxígeno disuelto al efluente final en un $6 \%$ (desgasificador).

Las variables productivas analizadas: incremento de peso y talla, conversión alimenticia, mortalidad y producción; se encontraron dentro de los valores normales de producción piscícola de la especie cultivada. El sistema de recirculación evaluado inició con una carga de $3.5 \mathrm{~kg} / \mathrm{m}^{3}$ y finalizó con una carga de $12.1 \mathrm{~kg} / \mathrm{m}^{3}$, indicando un incremento de la biomasa del $345 \%$. El porcentaje de mortalidad registrado durante todo el periodo de estudio fue del $4,9 \%$.

\section{Agradecimientos}

A la VIPRI de la Universidad de Nariño, al Profesor Roberto Salazar Cano y a los estudiantes del Programa Ingeniería en Producción Acuícola: Karen Larrañaga; Viviana Cárdenas; Carlos Caicedo; Luis Enríquez; Diego Miramac; Adriana Arce; Silvia Bolaños; Félix Jojoa; Lorena Ortega; Diana Beltran y Nataly Sarasty.

\section{REFERENCES}

1. Li X, Li J, Wang Y, Fu L, Fu Y, Li B et al. Aquaculture Industry in China: Current State, Challenges, and Outlook. Reviews in Fisheries Science 2011; 19(3): 187-200.

2. Ouyang Y, Parajuli PB, Marion DA. Estimation of surface water quality in a Yazoo River tributary using the duration curve and recurrence interval approach. Water Science \& Technology: Water Supply 2013; 13(2): 515-523.

3. Padilla AF. Fundamentos de Acuicultura. Monteria: Publication service, Universidad de Cordoba; 2009.

4. Hanasaki N, Fujimori S, Yamamoto T, Yoshikawa S, Masaki Y, Hijioka Y et al. A global water scarcity assessment under shared socioeconomic pathways - Part 1: Water use. Hydrol Earth Syst Sci Discuss 2012; 9:13879-13932.
5. IDEAM. National Water Study. Bogota D.C.: Institute of Hydrology, Meteorology and Environmental Studies; 2010.

6. Badiola M, Mendiola D, Bostock J. Recirculating Aquaculture Systems (RAS) analysis: Main issues on management and future challenges. Aquacult Eng. 2012; 51: 26-35.

7. Hutchinson W, Jeffrey M, O'Sullivan D, Casement $D$, Clarke S. Recirculating aquaculture systems minimum standards for design, construction and management. Kent Town: Inland Aquaculture Association of South Australia Inc.; 2004.

8. Li X, Li G, Zhang S, Tao L. Effect of Recirculating Aquaculture System (RAS) on Growth Performance, Body Composition and Hematological Indicators of Allogynogenetic crucian Carp (Carassius auratus gibelio). Advance Journal of Food Science and Technology 2013; 5(3): 348-355. 
9. von Sperling M. Introduccion a la calidad del agua y al tratamiento de aguas residuales - Principios del Tratamiento Biologico de Aguas Residuales, Volume 1. $1^{\text {st }}$ Spanish Edition. San Juan de Pasto, Colombia: University Editing House of University of Nariño; 2012.

10. Food and Agriculture Organization of the United Nations - FAO. The State of World Fisheries and Aquaculture 2012. Rome: FAO Fisheries and Aquaculture Department; 2012 p.

11. Timmons MB, Ebeling JM. Recirculating aquaculture. $2^{\text {nd }}$ Edition. New York: NRAC Publication No. 401-2010 Cayuga Aqua Ventures; 2010.

12. World Weather Information Service. [Online]. Colombia, Institute of Hydrology, Meteorology and Environment Studies, Weather Information for Pasto; 2013. URL Available at: http://worldweather.wmo.int/057/c00878.htm.

13. American Public Health Association (APHA), American Water Works Association (AWWA), Water Environment Federation (WEF). Standard Methods for the Examination of Water and Wastewater. 20 ed. Washington, D.C.; American Public Health Association: 1998.

14. Moogouei R, Karbassi AR, Monavari SM, Rabani $M$, Taheri Mirghaed A. Effect of the selected physicochemical parameters on growth of rainbow trout (Oncorhynchus mykiss) in raceway system in Iran. Iran J Fish Sci 2010; 9(2): 245-254.

15. Malone RF, Pfeiffer TJ. Rating fixed film nitrifying biofilters used in recirculating aquaculture systems. Aquacult Eng 2006; 34(3): 389-402.

16. Colt J. Water quality requirements for reuse systems. Aquacult Eng 2006; 34(3): 143-156.

17. Algers B, Blokhuis HJ, Bøtner A, Broom DM, Costa $\mathrm{P}$, Domingo $\mathrm{M}$ et al. Scientific Opinion of the Panel on Animal Health and Welfare on a request from the European Commission on Species-specific welfare aspects of the main systems of stunning and killing of farmed rainbow trout. The EFSA Journal 2009; 1013: 1-55.

18. Eding EH, Kamstra A, Verreth JAJ, Huisman EA, Klapwijk A. Design and operation of nitrifying trickling filters in recirculating aquaculture: $\mathrm{A}$ review. Aquacult Eng 2006; 34(3): 234-260.
19. Republic of Colombia, Ministry of Economic Development - Drinking Water and Basic Sanitation Department. Drinking Water and Sanitation Sector Technical Regulation RAS 2000. Bogota: Ministry of Economic Development; 2000.

20. Al-Hafedh YS, Alam A, Alam MA. Performance of plastic biofilter media with different configuration in a water recirculation system for the culture of Nile tilapia (Oreochromis niloticus). Aquacult Eng 2003; 29(3-4): 139-154.

21. Lekang O, Kleppe H. Efficiency of nitrification in trickling filters using different filter media. Aquacult Eng 2000; 21(3): 181-199.

22. Spellman FR. Handbook of Water and Wastewater Treatment plant Operations. $2^{\text {nd }}$ Edition. Boca Raton, Florida: CRC Press; 2009.

23. Romero RJA. Tratamiento de aguas residuales. Teoria y principios de diseño. Third edition. Bogota, Colombia: Editorial Escuela Colombiana de Ingenieria; 2004.

24. Lekang OI. Aquaculture Engineering. Oxford: Blackwell Publishing; 2007.

25. Baylar A, Bagatur T. Aeration performance of weirs. Water SA 2000; 26(4):521-526.

26. Baylar A, BagaturT, Tuna A. Aeration Performance of Triangular Notch Weirs at Recirculating System. Water Qual Res J Canada 2001; 36(1): 121-132.

27. Ministry of Agriculture and Rural Development; 2005. Observatorio Agrocadenas Colombia, Working Document No. 72: La Cadena de la Piscicultura en Colombia, una Mirada Global de su Estructura y Dinamica, 1991-2005. URL Available at: http://www.agronet.gov. co/www/docs_agronet/2005112164315_ caracterizacion_piscicultura.pdf.

28. Arredondo J, Barriga I, Georgina L, Ponce J. Cultivo de Trucha Arcoiris (Oncorhynchus mykiss, Walbaum) en un sistema cerrado de recirculacion de agua. Reports of the IV Virtual Iberoamerican Congress of Aquaculture CIVA. Mexico; 2006. URL available at: http://www.revistaaquatic.com/civa2006/coms/ completo.asp?cod=197.

29. Van Rijn J. Waste treatment in recirculating aquaculture systems. Aquacult Eng 2013; 53:49-56. 